\title{
Parliamentary representation: A cross-national study of candidates' views
}

\begin{abstract}
This study explores political elites' self-conceptualisation of parliamentary representation by using data on nearly 7,000 candidates encompassing eighteen elections in fifteen countries. We examine the relevance of institutional features, closeness to the sources of representatives' mandates, party family, as well as candidates' personal characteristics, with a modelling strategy that accommodates the understanding of role orientation as a two-stage process. We posit that choosing between being loyal to a party or to voters is not equivalent to prioritising one's own agency in the first place, and suggest that self-conceptualisation of parliamentary representation happens in two different stages. We find that individual-level characteristics such as gender and ideological proximity to one's party, but also party family, play a key role in shaping views on authority versus independence. The effects of political environment and institutions are limited to shaping a choice between responding to one's party or constituents.
\end{abstract}

Keywords: Representation, political elites, role perception, delegate, trustee, partisan 


\section{Introduction}

Representation is one of the most debated, disentangled, and contested concepts in the study of the democratic process. This is unsurprising given that modern democracy is by definition representative. Studies of citizens' perception of representation have uncovered how public representatives are expected to behave (e.g., Méndez-Lago and Martínez 2002; Carman 2006; Bengtsson and Wass 2010; André and Depauw 2017), and we have a good understanding of what politicians do from analyses of roll call data and parliamentary questions (Hix et al. 2007; Saalfeld 2011). However, less attention has been paid to what political elites perceive the role of elected representatives to be, with particularly scarce evidence from a comparative perspective. This study addresses this issue by exploring candidates' role orientation using data from the cross-national Comparative Candidates Study (CCS) project on nearly 7,000 candidates in fifteen countries. It offers the largest pool of candidate data to date, including both challengers and incumbents.

Studies of role orientation among the individuals who make up legislatures are crucial, given the consequences of their actions on governance. Our approach aids this in two ways. First, it sheds light on the preferred behaviour of public representatives in complex situations. For instance, in a context like contemporary Britain where members of parliament (MPs) face the consequences of the June 2016 Brexit vote, role orientation could help anticipate - or at least understand - how they act in parliament when faced with voting dilemmas. Second, our cross-sectional data allow us to contribute to the open debate on whether certain demographic and social characteristics lead to substantially different interpretations of the role of public representatives, ceteris paribus. For instance, Cowley and Childs (2003) found evidence "of a different, women's, style of political behaviour", which hints to the possibility of gender defined understandings of representation. On the other hand, Weßels (1999) found the effects of personal characteristics to be limited, at least among Members of the European Parliament. Our study contributes to this open debate, lending some support for the former.

Normative concerns about representation have motivated a long tradition of studies, focusing on satisfaction with democracy (Aarts and Thomassen 2008; Dalton 2008), perceptions of political efficacy (Finkel 1985), and political participation (Reher 2014). Recently, multiple studies of representation have outlined citizens' views on how the democratic process should take place and how politicians should behave (Bengtsson and Wass 2010; André and Depauw 2016; Bowler 2017). This has brought some clarity on public attitudes towards parliamentary 
representation, leading to a greater understanding of what the expectations are on the demand side of the representation equation.

The study of the supply side, in contrast, has taken a predominantly behavioural approach by focusing on roll call records and parliamentary questions asked by MPs. After all, the actions of elected representatives demonstrate the type of approach they opt for when fulfilling their role. However, representation goes above and beyond roll call votes, legislative debates, and electoral success; it is determined by the understanding of its meaning for those who are, or seek to be, public representatives. This has been outlined in contemporary theory on the subject (Rehfeld 2009; Saward 2010; de Wilde 2013), but empirical studies of parliamentary behaviour often fall short of insights into how politicians truly conceive representation.

This is not to say suggest that the issue of role perception has not been addressed by previous research. For instance, Deschouwer and Depauw's collection (2014) increased our knowledge of politicians' role conceptions, offering insights from over 2,000 MPs in the fifteen countries involved in the PARTIREP project. Using a comparative approach, they show that systemic and institutional features contribute to shaping perceptions of representation among MPs. In addition, case studies have shown party-level factors to be of great importance (Weßels and Giebler 2010; Chiru and Enyedi 2015). However, the extent to which politicians' individuallevel characteristics interplay with structural incentives remains largely underexplored from a truly cross-national perspective. For example, Dudzińska et al. (2014) use comparative data to analyse styles of representation, but do not look at individual-level factors. To gather a fuller picture of what shapes role perception, we account for institutional features, closeness to the sources of representatives' mandates, party family, as well as candidates' personal characteristics, with a modelling strategy that accommodates the understanding of selfconceptualisation of agency as a two-stage process. This sets apart those who view MPs as independent agents (trustees) from those who believe that MPs should act on behalf of an external authority. Within this latter group, some suggest that MPs should respond to their voters (delegates), whereas others envisage MPs as loyal agents of their party (partisans).

Our findings indicate that individual-level and party-level characteristics are more important, relative to macro-level features, at the first stage of the representation process. Candidates' demographic characteristics, their ideological proximity to the party, and party family are key to defining whether they perceive MPs as trustees or not. Importantly, we unveil a significant 
gender difference, the consequences of which need to be explored further. In the second stage of the process, where the choice is between viewing MPs as partisans or delegates, the picture is more complex. Electoral rules emerge as significantly more important than in the first stage and a broader range of individual-level indicators contribute to explaining whether candidates expect MPs to be partisans or delegates. Taken together, this indicates that the importance of electoral institutions may be overstated, as already also suggested by others (Ghergina 2011; Martin 2014).

The paper is organised as follows. First, we discuss the existing literature on representation in relation to our theory. Following on, we outline the two-stage process of representation and our expectations. We then describe the data and explain our methodological approach. In the final two sections, we present and discuss our results and their broader implications.

\section{Representation as a two-stage process}

The body of literature on representation has traditionally relied on normative accounts of what the functions and duties of elected representatives should be, leading to the formulation of various theoretical models and archetypes of parliamentary representation (e.g., Wahlke and Eulau 1959; Pitkin 1967; Converse and Pierce 1986; Andeweg and Thomassen 2005). The richness of this literature has led to considerable diversity in the conceptualisation of representation (e.g., Searing 1994; Thomassen and Esaiasson 2006). However, despite such diversity, an element of broad agreement in this literature is the existence of three (ideal) types of elected representatives: delegates, partisans, and trustees. ${ }^{1}$ Delegates are depicted as acting first and foremost on behalf of their constituents, with the preferences and priorities of their voters taking precedence over those of their own and their party. Partisans are those who follow their party line and respect party discipline even if it means discarding the preferences of their voters and those of their own. Finally, trustees value their own expertise and prioritise their own judgements above the preferences of their constituents and those of their party. The crucial nuance here is that partisans and delegates are elected representatives who choose to respond to an external authority, whereas trustees are independent-minded agents.

\footnotetext{
${ }^{1}$ The partisan type was originally conceived as an extension of the delegate type and not part of the taxonomy (Wahlke and Eulau 1959; Wahlke et al. 1962). However, it is now widely accepted that a threefold classification captures more realistically the pressures that elected representatives face given the importance of party loyalty in modern legislatures (Converse and Pierce 1986; Andeweg and Thomassen 2005).
} 
The implicit assumption in the studies using this trustee-partisan-delegate typology is that the three types are equivalent, whereby parliamentary representation can be conceptualised as a clear-cut choice between these different, but parallel, types (Rehfeld 2009). This is evidenced by the fact that studies detailing this distinction employ multinomial logistic models (Dudzińska et al. 2014; Chiru and Enyedi 2015), which assume equivalence across outcomes. We argue that there are theoretical and empirical reasons to separate self-conception into two stages. Weßels and Giebler (2010) hint at this by showing that trustees' profiles are less clear than partisans or delegates, with more disagreement within the group. We build on this by first modelling representation as a choice between independent-mindedness or not. As such, we depart from the above assumption and posit that choosing between being loyal to a party or to voters is not equivalent to prioritising one's own agency in the first place, and suggest that self-conceptualisation of parliamentary representation happens in two stages. In other words, one makes an initial choice of whether MPs should hold independent agency or respond to an external authority. If the latter, one then faces another choice of whether MPs should serve their party or constituents.

The model we put forward to conceptualise representation reconciles the distinction between viewing parliamentary representation as a matter of style or focus. There is no universal way of applying the trustee-partisan-delegate typology in existing literature as scholars have relied on slightly different interpretations of what the process of choosing the preferred vision of representation exactly entails. In the early literature on representation, Wahlke et al. (1962) introduced a distinction between style and focus, capturing slightly different aspects of how parliamentary representation can be envisaged. On the one hand, the corpus of research on style tends to discuss what the role of an elected representative should be (Andeweg 2012; Önnudóttir 2016). It portrays parliamentary representation mainly as a function of personal beliefs and experiences. On the other hand, studies of focus tend to explore how important elected representatives see, or should see, the representation of different stakeholders and their preferences (Chiru and Enyedi 2015; André and Depauw 2016). This strand describes parliamentary representation as a rational and calculated response to an external authority. However, style clearly influences focus, and the two cannot be neatly separated (Weßels and Giebler 2010; Dudzińska et al. 2014).

In combining these traditions, our approach incorporates style in the first stage of the process when considering how parliamentary representation ought to be carried out (i.e., as exercising 
independent agency or responding to an external authority) and focus in the second stage (i.e., which external authority should MPs respond to). This overarching model harmonises what has largely been a fragmented approach to studying representation. We posit that politicians have to make the more fundamental decision of whether independent agency or external authority should take priority before thinking about which groups and principals to represent. While based on a substantive corpus of literature on representation, our approach is novel in the extent to which it simultaneously captures two sets of interrelated, if distinct, choices. In the next section, we outline and motivate the expectations we hold for each of the two stages.

\section{Expectations}

Individual-level characteristics and institutional elements are both likely to influence elites' attitudes towards representation. With regards to the first stage, where political elites decide if MPs should be independent-minded trustees or respond to an external authority, we expect individual-level characteristics to stand out. For an elected representative, discarding the views of her party and constituents, in favour of her own position, is a difficult and potentially damaging decision. It is a decision that will be perceived unfavourably by the principals whose support she needs for gaining re-election, requiring considerable personal conviction and trust in oneself. Therefore, we expect candidates' likelihood of seeing MPs as trustees to be driven by their own political experience and demographic characteristics.

Those experienced as decision-makers within their party organisation or an elected political office - local or national - should be more confident in their own agency and more likely to perceive MPs as independent-minded trustees (Hafner-Burton et al. 2013). Following the same rationale, older politicians should be more experienced and, therefore, more likely to believe that MPs should act as trustees. In addition, research in political psychology finds that men tend to be more comfortable defending their own views (Kalaian and Freeman 1994; Albarracín et al. 2012; Lausberg 2016), shaping our expectation that men will be more likely to view MPs as trustees than women.

We also expect the type of party one is affiliated with to matter. In formulating expectations about those differences - and testing them empirically - taking a benchmark proves useful. We organise expectations in relation to Green parties as they have a long tradition of advocating decentralisation as a policy and organisational principle. They share preference for party structures that are bottom-up, disperse power, and empower individual members 
(Miragliotta and Jackson 2015). This would imply that Green parties, and their candidates, are more inclined to value the independence of MPs and believe they should act as trustees than candidates belonging to other parties.

Although some studies have found that electoral rules shape whether MPs see themselves as trustees or not (Dudzińska et al. 2014), others have found that institutions have a limited role (Blomgren and Rozenberg 2012) or that country-specific context matters more (Önnudóttir 2016). We expect electoral context to have no significant effect when individual-level characteristics and party family are fully accounted for.

Conversely, in the second stage - where those who opt for responding to an external authority face the choice between constituents and party - we expect contextual factors to play a key role in determining which principal one believes that MPs should respond to. Studies of both candidates (Sudulich and Trumm 2017) and elected representatives (Chiru and Enyedi 2015; Önnudóttir 2016; von Schoultz and Wass 2016) have shown that institutions shape how they behave. It is reasonable, therefore, to expect that electoral system and district magnitude also influence the strategic choice between principals. The more party-centred an electoral system is, the stronger the incentives for politicians to be loyal to their party. For example, politicians in a closed-list PR system depend on their party for electoral success as it is the party that controls access to party ticket and ballot placement, whereas politicians in candidate-centred systems like open-list PR must rely on their own profile and name recognition for electoral success. In addition, larger districts tend to disincentivise the creation of personal ties with one's constituents. Politicians are ultimately strategic in their choices (Heitshusen et al. 2005; André and Depauw 2013). Therefore, we expect candidates to be more likely to say that MPs should be partisans in countries with more party-centred electoral rules and larger district magnitudes. Finally, belonging to a party in opposition provides additional incentives for politicians to make common cause to defeat the government, resulting in stronger party attachment.

Individual-level characteristics and closeness to the two principals - party and constituents are also likely to matter in the second stage. Candidates who are living in the community they contest an election are likely to feel greater affection to that constituency, whereas candidates whose ideological positions align weaker with their party are likely to find the prospect of going against one's party more acceptable. Therefore, both should be more likely to suggest 
that MPs ought to act as delegates. On the other hand, greater political experience should push candidates towards seeing MPs as partisans. The experience of working within party office or holding political office socialises individuals within the political system and creates ties with the party. Therefore, candidates with such experience should value loyalty to party higher and be more inclined to see MPs as partisans instead of delegates.

The impact of party family is less predictable in the second stage as all parties have equal incentives to exert some control over the behaviour of their parliamentary party. Although Green party candidates tend to have more independence, there is no evidence that they form particularly close relationships with their constituents (Miragliotta and Jackson 2015). On the other hand, there is some evidence to suggest that right-leaning parties, such as Conservatives or Christian democrats, prefer a constituency focus (Dudzińska et al. 2014; von Schoultz and Wass 2016).

Table 1 summarises our expectations. We describe the first stage as a choice between seeing MPs as responding to an authority (outcome 1) or independent-minded trustees (outcome 0) and the second stage as a choice between seeing MPs as partisans (outcome 1) or delegates (outcome 0 ). In both stages, the expectations are expressed in relation to outcome 1 .

\section{[TABLE 1 HERE]}

\section{Data and methods}

We evaluate our theoretical expectations using information on candidates running for office in first-order parliamentary elections. The main data source is the cross-national CCS project. It brings together a wide range of national candidate studies and uses a common core questionnaire to allow for cross-country analyses. In order to maximise the coverage of countries in this study, we merge data from Module 1 and Module 2 of the CCS (2016, 2018). ${ }^{2}$ As a result, we have information on all the variables of interest for fifteen elections, accounting for a total of 6,870 candidates. ${ }^{3}$ These data have several advantages as they i)

\footnotetext{
${ }^{2}$ See Table S1 in the supplementary material for the list of countries and elections included in the analysis. Information on the common core questionnaire, country-specific field work, and access to datasets is available at http://www.comparativecandidates.org.

${ }^{3}$ This sample includes candidates from a single election for thirteen out of fifteen countries. For two countries, Sweden and Switzerland, candidates from multiple elections are included. Estimates from models that restrict the sample to a single election for all countries are robust to those presented here.
} 
include a diverse range of countries in terms of their electoral systems and political history, ii) are based on surveys that were conducted within a few years of each and used a common core questionnaire ${ }^{4}$, iii) capture respondents' personal background and attitudes, iv) include identifiers for respondents' party and country, and v) include both incumbents and challengers. ${ }^{5}$

\section{Dependent variables}

The CCS includes a series of questions capturing respondents' views towards representation. We rely here on the survey questions that ask respondents whose interests they believe MPs ought to prioritise when faced with hypothetical conflicts of interest. ${ }^{6}$ It is only when a choice must be made between the views of different actors when one's true vision of representation is revealed.

In line with our theoretical approach, we develop two dependent variables to capture how candidates believe that MPs should approach parliamentary representation. Authority captures whether the candidate believes that MPs should be independent-minded politicians or not. It is coded 1 for respondents who believe that, if faced with a choice, MPs should respond to an external authority (party or constituents), and 0 for respondents who believe that MPs should follow their own views over those of their constituents and party instead. Partisan-delegate, then, makes a further distinction among candidates who believe that MPs should respond to an external authority of some kind. It distinguishes between candidates who believe that, if in conflict, MPs ought to prioritise their party positions over their own preferences and those of their voters (coded 1) and those who believe that MPs should vote in line with their voters' preferences even if these go against their party position and their own views (coded 0$)$. Taken together, we capture whether candidates envisage MPs as independent-minded politicians or not, and, if not, whether they believe that MPs should prioritise the preferences of their voters or those of their party.

Table 2 shows the breakdown of candidates based on how they believe MPs should approach representation, offering an overview of the distribution of both dependent variables. ${ }^{7} \mathrm{We}$

\footnotetext{
${ }^{4}$ National country teams were at freedom to drop or rephrase questions to best fit the local context.

${ }^{5} \mathrm{We}$ include both incumbents and challengers in the analysis as this provides a more complete picture of which views on representation the public is exposed to.

${ }^{6}$ The exact wording of survey questions is provided in Table S2 in the supplementary material.

7 The descriptive statistics in Table 2 is based on the sample that is used in the following multivariate analysis.
} 
present the percentage of candidates who see MPs as responsive to an authority and, among those, the breakdown of partisans and delegates, by country. There is clearly no predominant view of how MPs should behave. Almost half of the sample of candidates believes that acting as a trustee and being an independent-minded politician is the appropriate behaviour for an MP when facing a conflict of preferences (46.5\%), with the other half (53.5\%) being almost evenly divided between those who view MPs as partisans (57.4\%) and those who think of MPs as delegates (42.6\%). One intuitive explanation for the country-level differences could be electoral institutions; however, if we take a closer look at the figures we encounter several counter-intuitive patterns. The low levels of partisans, among those who believe that MPs should respond to an external authority, in Montenegro (35.3\%) and Portugal (45\%) where closed-list PR is used does not support this intuition, nor does the high level of partisans in the Netherlands (90.9\%) where ordered-list PR is used. This does of course not necessarily mean that electoral institutions are irrelevant, and their potential relevance should be explored in a more systematic manner, but it does suggest that individual-level factors might have an even greater role in explaining how political elites think about parliamentary representation.

\section{[TABLE 2 HERE]}

\section{$\underline{\text { Key explanatory variables and controls }}$}

To shed light on what explains holding contrasting visions of parliamentary representation, we capture the institutional context within which candidates operate, their relationship with their party and constituents, as well as their political and personal profile. ${ }^{8}$

With regards to institutional incentives, we focus on the potential relevance of electoral rules and governmental status in shaping how candidates view parliamentary representation. In line with the study by Farrell and Scully (2007), Electoral system captures how candidate-centred, versus party-centred, an electoral system is. It is measured on a six-point scale where higher values correspond to a more candidate-centred electoral system. ${ }^{9}$ Lower scores are attributed to countries that use systems like closed-list PR and higher scores to countries that employ systems like open-list PR and First-Past-the-Post. In addition, we explore the role of District magnitude in influencing candidates' attitudes. It taps into the closeness of the relationship

\footnotetext{
${ }^{8}$ See Table S3 in supplementary material for additional information on the explanatory variables.

${ }^{9}$ Estimates from models were electoral system is as majoritarian (1) versus proportional (0) are robust to those presented here.
} 
between an individual politician and her constituents. It is operationalised as the natural logarithm of the number of seats allocated in the constituency where the candidate stood for office. ${ }^{10}$ The use of natural logarithm is common practice in electoral studies literature and useful for correcting the skewed nature of the variable. Finally, incentives provided by belonging to a party that recently held power may differ from those provided by belonging to a party that did not. We distinguish between candidates who belonged to a party that was in Government in the run up to the election for which the survey is conducted (coded 1) from those who belonged to a party in opposition (coded 0$)$.

Candidates' relationship with their party and constituents is captured through two indicators. Ideological distance measures the absolute difference between candidates' left-right position and the left-right position of their party (as perceived by the candidates), ranging from 0 'no difference' to 10 'maximum difference'. It describes the self-perceived extent of ideological divergence between the candidate and her party. ${ }^{11} \mathrm{We}$ also control for whether candidates are physically embedded in the community they seek to represent or not. Locality distinguishes between candidates who live in the constituency they stand for election (coded 1) and those who do not (coded 0). It is likely that candidates living in the constituency they run for office are more invested in constituency matters, in terms of both awareness and attachment.

Party-level effects are captured through the variable Party family. It is a categorical measure, capturing the following party families: Green/Ecologist, Socialist, Social democrats, Liberals, Christian democrats, Conservatives, Nationalist, Agrarian, Ethnic-regional, and

Finally, we account for candidates' political and personal profile. It is plausible that political experience and socialisation processes may have a bearing on how political elites see the role of elected representatives. Candidates' political profile and experience is captured by five variables. Party office local distinguishes between candidates who have held an office in their local party organisation (coded 1) from those who have not (coded 0), whereas Party office national separates candidates who have held an office in their national party organisation (coded 1) from those who have not (coded 0). Political office local distinguishes between

\footnotetext{
${ }^{10}$ District magnitude is a constituency-level measure. It can vary both across and within countries.

${ }^{11}$ A similar indicator for ideological distance between candidates' left-right position and the left-right position of their voters (as perceived by the candidates) is included in Module 2 of the CCS, but not in Module 1. Hence, this is not in used in the analysis presented here.
} 
candidates who have been elected to a local-level legislature or executive (coded 1) and those who have not (coded 0), with Political office national separating candidates who have been elected to a national-level legislature or executive (coded 1) from those who have not (coded 0). Finally, Likelihood of success distinguishes between candidates who believed they had a chance of getting elected before campaigning started (coded 1) and those who did not (coded $0)$. In addition, we use two demographic indicators of candidates' personal profile. Gender is operationalised as a dichotomous measure - Female - that makes a distinction between males (coded 0) and females (coded 1), whereas Age captures candidates' age (in years) at the time of the election. These two indicators of personal profile tap into the level of confidence one should have in own judgement and, therefore, are only included in the selection phase where candidates' likelihood of seeing MPs as trustees is explained. ${ }^{12}$

\section{Empirical strategy}

The two-stage conceptualisation of parliamentary representation is captured empirically by a selection model. We implement a Heckman probit model as both dependent variables are binary. ${ }^{13}$ Finally, we account for country-specific effects that go beyond electoral institutions by including country fixed effects as country dummies.

\section{Findings}

We turn our focus now to the multivariate analysis. Table 3 explains variation in candidates' likelihood of seeing MPs as independent agents or responsive to an external authority and, if the latter, as Partisans or Delegates.

In the first stage, institutional factors do not influence candidates' likelihood of seeing MPs as responsive to an external authority or being independent-minded agents. In line with the

\footnotetext{
${ }^{12}$ The inclusion of two explanatory characteristics in the selection phase only also satisfies the requirement in the specification of Heckman selection models to include at least one variable in the selection equation that is not in the outcome equation. It alleviates the problem of selection models being sensitive to correlation among covariates in the outcome and selection equations (Marra and Radice 2013).

${ }^{13}$ Heckman selection model (1979) is a method for estimating models which suffer from sample selection bias as the outcome variable (Y) is only observable when the value for another variable $(\mathrm{Z})$ is 1 . As such, it involves two equations: i) the selection equation considering which portion of the sample an outcome is observed for, and ii) the outcome equation considering the mechanisms determining the outcome variable. Heckman probit model used here is a variant of Heckman selection model, whereby the selection variable $(\mathrm{Z})$ and outcome variable $(\mathrm{Y})$ are both dichotomous. The strength of sample selection models is their ability to correct for non-random sample selection on the outcome variable. They have been used, for example, in voting behaviour literature to predict the decision to vote in contexts where voter registration is required (Timpone 1998) or in international relations when modelling conflict escalation as it is conditional upon getting involved in disputes (Palmer et al. 2004).
} 
expectations, there is no systematic effect associated with Electoral institutions or District magnitude on the dependent variable. Belonging to a party that was in government prior to the election is also unrelated to whether candidates view MPs as independent-minded agents or not. When it comes to the effects of Party family, all coefficients are significant and positive compared to Green parties. This is in line with previous findings showing that Green party candidates tend to be more independent-minded. In addition, the coefficient is strongest for special issue and nationalist party candidates, reflecting the cohesive discipline of such parties (Méndez-Lago and Martínez 2002).

\section{[TABLE 3 HERE]}

With regards to the indicators that capture candidates' relationship with the source of their mandate, we find candidates who are more ideologically distant from their party to be less likely to believe that MPs should respond to an external authority. This is unsurprising as ideological distance from one's party is likely to contribute to a broader sense of individual uniqueness and independence. The closeness of candidates to their constituents, however, is unrelated to whether they see MPs as someone who should respond to an external authority or be an independent-minded trustee.

Equally, and contrary to expectations, there are no statistically significant effects associated with candidates' political profile. The positive coefficient for Female, however, shows that women are more likely to expect MPs to respond to an external authority than men, which is in line with the existing evidence of men tending to be more comfortable defending their own views. Finally, the positive coefficient for Age, in contrast to our expectations indicates that older candidates are more likely to suggest that MPs should follow an external authority.

The second stage of the process highlights that predictors are indeed different in the extent to which they impact on the dependent variable. This signals that the two-stage strategy is an appropriate approach. Although we find no evidence of Electoral institutions shaping candidates' views, District magnitude has a significant effect in the expected direction. The positive coefficient of 0.22 for District magnitude means that candidates who are running in larger districts are more likely to see elected representatives as agents of their party than delegates, reflecting the disconnect that larger constituencies are seen to create between voters and candidates (Carey and Shugart 1995). 
In terms of individual-level characteristics, all indicators of political experience have positive effects on seeing MPs as partisans. The coefficients of 0.23 and 0.15 show, respectively, that candidates who have worked in their Local party office and held Local political office are more likely to see MPs as partisans than those without such experience. The same also holds for the corresponding national-level indicators. Candidates who have worked in National party office and held National political office are more likely to see MPs as partisans, as seen by the respective coefficients of 0.21 and 0.20 . It is evident that previous experience working in party office and holding political office encourage loyalty to party above the voice of one's voters.

Differences across parties are less profound in the second stage. We find that candidates from Conservative, Social democratic and Socialist parties are more likely to see representation in partisan terms. This reflects previous findings that highly ideological parties, such as socialist parties, tend to favour party unity over constituency focus (Andeweg and Thomassen 2005), but goes against expectations in the case of conservative parties.

Given the binary nature of both dependent variables, the interpretation of effect sizes is not intuitive. Therefore, we present predicted values for both outcomes as predicted probabilities in Table $4{ }^{14}$ Each particular characteristic is allowed to vary, whereas others are held constant at either their mean for continuous variables or mode for nominal variables.

\section{[TABLE 4 HERE]}

Ideological distance has the largest impact on the probability of seeing MPs as responsive to an external authority or an independent-minded agent when comparing the effects associated with minimum-to-maximum shifts in explanatory variables. The probability of seeing MPs as politicians who should respond to an external authority increases by $17 \%$ (from $38 \%$ to $55 \%$ ) when comparing candidates whose left-right position is in perfect alignment with that of their party to candidates who consider themselves most ideologically distant from their party. Onepoint increase in the ideological distance (ranging from 0 to 10) corresponds, on average, to a

\footnotetext{
${ }^{14}$ For the significant predictors, we present shifts from minimum to maximum, with the exception of Age, where minimum and maximum are outliers rather than meaningful values. In this case, evaluating a shift from the $25^{\text {th }}$ to the $75^{\text {th }}$ percentile is preferable. In the case of Party family, we provide a discussion in the text.
} 
$1.7 \%$ increase in the likelihood of viewing MPs as trustees. A shift in age from the value of the $25^{\text {th }}$ percentile (35 years) to the $75^{\text {th }}$ (56 years) shows a $4 \%$ increase in the likelihood of seeing MPs as responsive to an external authority, while women are 5\% more likely to see MPs as politicians who should be responsive to an external authority than men (58\% versus $53 \%$ ). Both effects are of interest if modest in size. The former contradicts our expectations sowing that younger age correlates with independence while the latter confirms that men are more prone to opt for independence from authorities. With regards to party family, candidates of Special issue and Nationalist parties stand out as being particularly inclined to advocate responsiveness to an external authority. These candidates are $34 \%$ and $28 \%$ more likely, respectively, to believe that MPs ought to respond to an external authority, instead of being an independent-minded trustee, than Green party candidates.

The effects emerging in the second stage are larger. District magnitude stands out here, with a minimum-to-maximum shift corresponding to a 39\% increase (from 35\% to 74\%) in one's likelihood of envisaging MPs as partisans instead of delegates. This effect remains substantial even when excluding countries like the Netherlands and Montenegro where single nationwide constituencies are used and focusing on a smaller minimum-to-mean shift. Such a shift in District magnitude corresponds to an $18 \%$ increase in candidates' likelihood of seeing MPs as partisans (from $35 \%$ to $53 \%$ ). Notable effects are also associated with indicators related to candidates' political profile. Local-level experience matters as candidates who have worked in local party organisation are 9\% more likely to see MPs as partisans than those who have not (53\% versus $44 \%$ ), whereas candidates who have held a local political office are $6 \%$ more likely to see MPs as partisans than those who have not (53\% versus 47\%). The same is true with national-level experience as candidates who have worked within the national party organisation are $8 \%$ more likely to see MPs as partisans than those who have not (61\% versus $53 \%$ ) and candidates who have held a national political office are $7 \%$ more likely to think of MPs as partisans than those who have not (60\% versus 53\%). Greater political experience, at local and national level, relates to a more party-centred view of parliamentary representation.

\section{Conclusion}

Parliamentary representation is a fluid concept as there is no universally accepted idea of how parliamentarians should act when carrying out their duties and whose preferences they should prioritise when facing conflicts of opinion. We captured the views of nearly 7,000 candidates from fifteen countries, ranging from first time novices to established political leaders, to 
examine how visions of representation are distributed among political elites. The picture that emerges shows an almost 50-50 split between those who envisage MPs as independentminded actors and those who feel that MPs are compelled to act on behalf of an external authority. Among this latter group, there is another 50-50 split between those who see the role of MPs as prioritising the interests of their party versus their constituents. The views of contemporary political elites on parliamentary representation are highly heterogeneous.

If we were to take the rational choice model, political elites, conscious of the ephemerality of being an MP, should believe that MPs need to prioritise the interests of whatever actor is best placed to improve their re-election chances. Yet, a large percentage of them envisage the role of MPs as being independent-minded agents and the importance of the political environment in which they operate in shaping their views a lot less impactful than expected. The relevance of political environment is largely limited to explaining whether someone envisages MPs as partisans or delegates, if they believe that MPs should respond to an external authority, in the first place.

There are three broader points arising from this study. First, the findings suggest that electoral institutions have a more limited influence on political views than often assumed. It is widely accepted that electoral institutions are vital to shaping political behaviour and the makeup of political institutions. They influence voting, campaign strategy, representation of women and minorities, etc. ${ }^{15}$ However, when it comes to how political elites think about parliamentary representation, the effects associated with electoral institutions are limited. We only find one element of electoral institutions, district magnitude, to have an impact upon candidates' views on parliamentary representation and even that to a limited extent. District magnitude does not influence candidates' likelihood of viewing MPs as responsive to an external authority or not, only their likelihood of thinking about MPs as partisans or delegates if they do believe that MPs should be responsive to an external authority. This is at odds with the neo-institutionalist approach, as it shows that politicians are not necessarily restricted by institutions when it comes to role orientations (Blomgren and Rozenberg 2012). In line with other studies that focus on relevance of individual-level factors, we find that candidates' background does greatly affect their views on representation (van Onselen 2004; Erzeel et al. 2014).

\footnotetext{
${ }^{15}$ See, for example, Norris and Inglehart (2001), Karp et al. (2008), Sudulich and Trumm (2017).
} 
Second, we unveiled a significant - if small - gender difference, which consequences need to be explored further. This is in line with the argument that personal characteristics deeply define the way MPs behave in parliaments. On the other hand, a much broader range of factors, including electoral rules, shapes whether MPs are seen as partisans or delegates.

Finally, our findings have implications for the relationship between voters and political elites, and how detached they are from each other. In the United Kingdom, for example, voters are more inclined to believe that politicians look out for their own interests than the people they represent, are more concerned with fighting each other than furthering public interest, and care little about what their voters think (Fieldhouse et al. 2016). The evidence presented here lends some support to this rather cynical narrative. Candidates are less likely to believe that MPs should act as delegates, prioritising the views of their voters, than partisans or trustees. This is compounded by the fact that those who do see the role of MPs in delegate terms tend to be political novices instead of established political leaders. As politicians gain experience and stature, either through working within their party organisations or holding public offices, they become more likely to support a party-centred view of parliamentary representation than a voter-centred one. Given that this goes against how voters believe MPs should behave when carrying out their legislative duties (Carman 2006; Bengtsson and Wass 2010; Bowler 2017), our findings suggest that the gap between elites and voters may be widening, with worrying consequences for the health of the democratic process.

Our contribution comes with limitations. While the CCS provides data on a large number of individual candidates and countries, country teams vary in the extent to which they adhere to the common questionnaire. This creates trade-offs between consistency of measures and number of cases to be included; we opted for rather parsimonious models that secured larger country reach. Keeping questionnaires stable over time and across context poses challenges to any research team, but could enable for a range of additional elements to be accounted for. Ideally, future data collection efforts will address this and provide stronger capacity for integration with national election studies so that elites and mass data can be taken together. 


\section{Bibliography}

Aarts, K. and Thomassen, J. (2008) 'Satisfaction with Democracy: Do Institutions Matter?', Electoral Studies, 27, 5-18.

Albarracín, J., Wang, W. and Albarracín, D. (2012) 'Are Confident Partisans Disloyal? The Role of Defensive Confidence in Party Defection', Journal of Applied Social Psychology, 42, 1576-1598.

Andeweg, R.B. (2012) 'The Consequences of Representatives' Role Orientations: Attitudes, Behaviour, Perceptions', In: Blomgren, M. and Rozenberg, O. (eds.) Parliamentary Roles in Modern Legislatures, London, Routledge, pp. 66-84.

Andeweg, R.B. and Thomassen, J.J.A. (2005) 'Modes of Political Representation: Toward a New Typology', Legislative Studies Quarterly, 30, 507-528.

André, A. and Depauw, S. (2013) 'District Magnitude and Home Styles of Representation in European Democracies', West European Politics, 36, 986-1006.

André, A. and Depauw, S. (2016) 'Looking Beyond the District: The Representation of Geographical Sub-Constituencies across Europe', International Political Science Review, 39, 256-272.

André, A. and Depauw, S. (2017) 'The Quality of Representation and Satisfaction with Democracy: The Consequences of Citizen-Elite Policy and Process Congruence', Political Behaviour, 39, 377-397.

Bengtsson, Å. and Wass, H. (2010) 'Styles of Political Representation: What Do Voters Expect?', Journal of Elections, Public Opinion and Parties, 20, 55-81.

Blomgren, M. and Rozenberg, O. (2012) 'Legislative Roles and Legislative Studies: The Neo-Institutionalist Turning Point?', In: Blomgren, M. and Rozenberg, O. (eds.) Parliamentary Roles in Modern Legislatures, London, Routledge, pp. 8-36. 
Bowler, S. (2017) 'Trustees, Delegates, and Responsiveness in Comparative Perspective', Comparative Political Studies, 50, 766-793.

Carman, C. (2006) 'Public Preferences for Parliamentary Representation in the UK: An Overlooked Link?', Political Studies, 54, 103-122.

Carey, J.M. and Shugart, M.S. (1995) Incentives to Cultivate a Personal Vote: A Rank Ordering of Electoral Formulas', Electoral Studies, 14, 417-439.

CCS (2016) Comparative Candidates Survey Module I - 2005-2013 [Dataset - Cumulative File]. Distributed by FORS, Lausanne, 2016.

CCS (2018) Comparative Candidates Survey Module II - 2013-2018 [Dataset - Cumulative File]. Distributed by FORS, Lausanne, 2018.

Chiru, M. and Enyedi, Z. (2015) 'Choosing Your Own Boss: Variations of Representation Foci in Mixed Electoral Systems', The Journal of Legislative Studies, 21, 495-514. Converse, P.E. and Pierce, E. (1986) Political Representation in France, Cambridge, The Belknap Press of Harvard University.

Cowley, P. and Childs, S. (2003) 'Too Spineless to Rebel? New Labour's Women MPs', British Journal of Political Science, 33, 345-365.

Dalton, R. (2008) 'Citizenship Norms and the Expansion of Political Participation', Political Studies, 56, 76-98.

de Wilde, P. (2013) 'Representative Claims Analysis: Theory Meets Method', Journal of European Public Policy, 20: 278-294.

Deschouwer, K. and Depauw, S. (2014) Representing the People: A Survey Among Members of Statewide and Substate Parliaments, Oxford, Oxford University Press.

Dudzińska, A., Poyet, C., Costa, O. and Weßels, B. (2014) 'Representational Roles', In: Deschouwer, K. and Depauw, S. (eds.) Political Representation and Legitimacy in the European Union, Oxford, Oxford University Press, pp. 19-38.

Erzeel, S., Caluwaerts, D. and Celis, K. (2014). 'From Agency to Institutions and Back', In: Deschouwer, K. and Depauw, S. (eds.) Political Representation and Legitimacy in the European Union, Oxford, Oxford University Press, pp. 66-86.

Farrell, D. and Scully, R. (2007) Representing Europe's Citizens? Electoral Institutions and the Failure of Parliamentary Representation in the European Union, Oxford, Oxford University Press.

Fieldhouse, E., Green, J., Evans, G., Schmitt, H., van der Eijk, C., Mellon, J. and Prosser, C. (2016) British Election Study, 2015: Face-to-Face Post-Election Survey, Available online at: http://dx.doi.org/10.5255/UKDA-SN-7972-1. 
Finkel, S. (1985) 'Reciprocal Effects of Participation and Political Efficacy: A Panel Analysis', American Journal of Political Science, 29, 891-913.

Gherghina, S. (2011) 'MPs' Role Orientations in Newly Emerged Democratic Legislatures', The Journal of Legislative Studies, 17, 45-64.

Hafner-Burton, E.M., Alex Hughes, D. and Victor, D.G. (2013) 'The Cognitive Revolution and the Political Psychology of Elite Decision Making', Perspectives on Politics, 11, 368-386.

Heckman, J.D. (1979) 'Sample Selection Bias as a Specification Error', Econometrica, 47, 153-162.

Heitshusen, V., Young, G. and Wood, D.M. (2005) 'Electoral Context and MP Constituency Focus in Australia, Canada, Ireland, New Zealand, and the United Kingdom', American Journal of Political Science, 49, 32-45.

Hix, S., Noury, A.G. and Roland, G. (2007) Democratic Politics in the European Parliament, Cambridge: Cambridge University Press.

Kalaian, H.A. and Freeman, D.J. (1994) 'Gender Differences in Self-Confidence and Educational Beliefs among Secondary Teacher Candidates', Teaching and Teacher Education, 10, 647-658.

Karp, J., Banducci, S. and Bowler, S. (2008) 'Getting Out the Vote: Party Mobilization in a Comparative Perspective', British Journal of Political Science, 38, 91-112.

Lausberg, A.K. (2016) 'Women and Representation: Cross-Party Collaboration in the Australian Federal Parliament', Parliamentary Affairs, 69: 249-268.

Marra, G. and Radice, R. (2013) 'Estimation of a Regression Spline Sample Selection Model', Computational Statistics and Data Analysis, 61, 158-173.

Martin, S. (2014) 'Why Electoral Systems Don't Always Matter: The Impact of 'Mega-Seats' on Legislative Behaviour in Ireland', Party Politics, 20, 467-479.

Méndez-Lago, M. and Martínez, A. (2002) 'Political Representation in Spain: An Empirical Analysis of the Perception of Citizens and MPs', The Journal of Legislative Studies, 8, 63-90.

Miragliotta, N. and Jackson, S. (2015) 'Green Parties in Federal Systems: Resistant or Compliant to Centralizing Pressures?, Government and Opposition, 50, 549-577.

Norris, P. and Inglehart, R. (2001) 'Cultural Obstacles to Equal Representation', Journal of Democracy, 12, 126-140.

van Onselen, P. (2004) 'Pre-Parliamentary Backgrounds of Australian Major Party MPs: Effects on Representation', The Journal of Legislative Studies, 10: 84-106. 
Önnudóttir, E.H. (2016) 'Political Parties and Styles of Representation', Party Politics, 22, $732-745$.

Palmer, G., London, T. and Regan, P. (2004) 'What's Stopping You? The Sources of Political Constraints on International Conflict Behavior in Parliamentary Democracies, International Interactions, 30: 1-24.

Pitkin, H.F. (1967) The Concept of Representation, Berkeley: University of California Press.

Reher, S. (2014) 'The Effect of Congruence in Policy Priorities on Electoral Participation', Electoral Studies, 36, 158-172.

Rehfeld, A. (2009) 'Representation Rethought: On Trustees, Delegates, and Gyroscopes in the Study of Political Representation and Democracy', The American Political Science Review, 103, 214-230.

Saalfeld, T. (2011) 'Parliamentary Questions as Instruments of Substantive Representation: Visible Minorities in the UK House of Commons, 2005-10', The Journal of Legislative Studies, 17, 271-289.

Saward, M. (2010) The Representative Claim, Oxford: Oxford University Press.

Searing, D.D. (1994) Westminster's World: Understanding Political Roles, Cambridge, Harvard University Press.

Sudulich, L. and Trumm, S. (2017) 'A Comparative Study of the Effects of Electoral Institutions on Campaigns', British Journal of Political Science First View, 1-19.

Thomassen, J. and Esaiasson, P. (2006) 'Role Orientations of Members of Parliament', Acta Politica, 41, 217-231.

Timpone, R.J. (1998) 'Structure, Behavior, and Voter Turnout in the United States', American Political Science Review, 92, 145-158.

von Schoultz, A. and Wass, H. (2016) 'Beating Issue Agreement: Congruence in the Representational Preferences of Candidates and Voters', Parliamentary Affairs, 69, 136-158.

Wahlke, J.C., Buchanan, W., Eulau, H. and Ferguson, L.C. (1962) The Legislative System. Explorations in Legislative Behavior, New York, John Wiley and Sons.

Wahlke, J.C. and Eulau, H. (1959) Legislative Behavior: A Reader in Theory and Research, Glencoe, The Free Press.

Weßels, B. (1999) 'Whom to Represent? Role Orientations of Legislators in Europe', In: Schmitt, H. and Thomassen, J. (eds.) Political Representation and Legitimacy in the European Union, Oxford, Oxford University Press, pp. 209-234. 
Weßels, B. and Giebler, H. (2010) Focus and Style - An Old Debate Revived, Available online at: https://www.researchgate.net/publication/228198206_Focus_and_Style__An_Old_Debate_Revived.

Fieldhouse, E., Green, J., Evans, G., Schmitt, H., van der Eijk, C., Mellon, J. and Prosser, C. (2016) British Election Study, 2015: Face-to-Face Post-Election Survey, Available online at: http://dx.doi.org/10.5255/UKDA-SN-7972-1.

Table 1. Expectations

\begin{tabular}{|c|c|c|}
\hline & $\begin{array}{c}\text { Responsive to authority } \\
\text { Stage } 1 \\
\end{array}$ & $\begin{array}{c}\text { Partisan over delegate } \\
\text { Stage } 2 \\
\end{array}$ \\
\hline \multicolumn{3}{|l|}{ Political context } \\
\hline Electoral system & & - \\
\hline District magnitude & & + \\
\hline Government & & + \\
\hline \multicolumn{3}{|l|}{ Party family^$^{\wedge}$} \\
\hline Socialist & + & - \\
\hline Social democrats & + & - \\
\hline Liberals & + & - \\
\hline Christian democrats & + & - \\
\hline Conservatives & + & - \\
\hline Nationalist & + & - \\
\hline Agrarian & + & - \\
\hline Ethnic-regional & + & - \\
\hline Special issue & + & - \\
\hline \multicolumn{3}{|l|}{ Closeness to external authority } \\
\hline Ideological distance & - & + \\
\hline Locality & + & - \\
\hline \multicolumn{3}{|l|}{ Political profile } \\
\hline Party office local & - & + \\
\hline Party office national & - & + \\
\hline Political office local & - & + \\
\hline Political office national & - & + \\
\hline Likelihood of success & - & + \\
\hline \multicolumn{3}{|l|}{ Personal profile } \\
\hline Gender & + & n.a. \\
\hline Age & - & n.a. \\
\hline
\end{tabular}

\footnotetext{
$\wedge$ Reference group is Greens.
} 
Table 2. Descriptive statistics on how MPs should behave

\begin{tabular}{lccc}
\hline & & \multicolumn{2}{c}{ Authority } \\
& Authority (\%) & Partisans (\%) & Delegates (\%) \\
\hline Albania & 87.5 & 53.3 & 46.8 \\
Australia & 67.6 & 46.1 & 54.0 \\
Belgium & 64.2 & 82.9 & 17.1 \\
Finland & 40.7 & 37.6 & 62.4 \\
Germany & 26.2 & 29.7 & 70.3 \\
Greece & 64.8 & 62.9 & 37.1 \\
Ireland & 81.0 & 81.3 & 18.8 \\
Italy & 65.0 & 47.2 & 52.8 \\
Montenegro & 79.7 & 35.3 & 64.7 \\
Netherlands & 54.6 & 90.9 & 9.1 \\
Norway & 74.3 & 74.5 & 25.5 \\
Portugal & 58.8 & 45.0 & 55.0 \\
Sweden & 68.7 & 73.7 & 26.4 \\
Switzerland & 30.0 & 43.0 & 57.1 \\
United Kingdom & 46.9 & 28.8 & 71.2 \\
\hline Overall & 53.5 & 57.4 & 42.6 \\
\hline
\end{tabular}


Table 3. Explaining differences in role perceptions

\begin{tabular}{|c|c|c|}
\hline & Authority (v. independence) & Partisan (v. delegate) \\
\hline Electoral system & $-0.09(0.07)$ & $0.02(0.08)$ \\
\hline District magnitude & $0.03(0.03)$ & $0.22 * *(0.04)$ \\
\hline Government & $0.03(0.04)$ & $0.09(0.06)$ \\
\hline \multicolumn{3}{|l|}{ Party family^^} \\
\hline Socialist & $0.48 * *(0.07)$ & $0.34 * *(0.12)$ \\
\hline Social democrats & $0.44 * *(0.07)$ & $0.49 * *(0.10)$ \\
\hline Liberals & $0.16^{*}(0.06)$ & $-0.02(0.10)$ \\
\hline Christian democrats & $0.36 * *(0.07)$ & $0.05(0.12)$ \\
\hline Conservatives & $0.32 * *(0.07)$ & $0.23 *(0.11)$ \\
\hline Nationalist & $0.81 * *(0.08)$ & $0.04(0.17)$ \\
\hline Agrarian & $0.43^{* *}(0.09)$ & $0.15(0.14)$ \\
\hline Ethnic-regional & $0.65 * *(0.12)$ & $0.15(0.18)$ \\
\hline Special issue & $0.99 * *(0.09)$ & $0.03(0.18)$ \\
\hline Ideological distance & $-0.05^{* *}(0.01)$ & $-0.02(0.02)$ \\
\hline Locality & $0.08(0.06)$ & $-0.17(0.09)$ \\
\hline Party office local & $-0.02(0.04)$ & $0.23 * *(0.06)$ \\
\hline Party office national & $-0.06(0.04)$ & $0.21 * *(0.06)$ \\
\hline Political office local & $0.01(0.04)$ & $0.15^{*}(0.06)$ \\
\hline Political office national & $0.00(0.05)$ & $0.20 * *(0.06)$ \\
\hline Likelihood of success & $-0.07(0.04)$ & $0.09(0.06)$ \\
\hline Female & $0.14 * *(0.03)$ & \\
\hline Age & $0.01 * *(0.00)$ & \\
\hline Constant & $0.65(0.58)$ & $-0.66(0.269)$ \\
\hline Country fixed-effects & yes & yes \\
\hline Observations & 6,870 & \\
\hline Censored observations & 3,197 & \\
\hline Uncensored observations & 3,673 & \\
\hline Log likelihood & $-6,292$ & \\
\hline
\end{tabular}

$\wedge$ Reference group is Greens. 
Table 4. Predicted probabilities

\begin{tabular}{|c|c|c|c|}
\hline & \multicolumn{3}{|c|}{ Equation 1 - Authority versus independence } \\
\hline & Minimum & Maximum & $\Delta$ (Max-Min) \\
\hline Ideological distance & $0.55(0.520 .57)$ & $0.38\left(\begin{array}{lll}0.30 & 0.47)\end{array}\right.$ & -0.17 \\
\hline \multirow[t]{2}{*}{ Female } & $0.53(0.500 .55)$ & $0.58(0.550 .60)$ & 0.05 \\
\hline & $25^{\text {th }}$ Percentile & $25^{\text {th }}$ Percentile & $\Delta\left(25^{\text {th }}-75^{\text {th }}\right)$ \\
\hline \multirow[t]{3}{*}{ Age } & $0.50(0.470 .53)$ & $0.54(0.510 .57)$ & 0.04 \\
\hline & \multicolumn{3}{|c|}{ Equation 2 - Partisan versus delegate } \\
\hline & Minimum & Maximum & $\Delta(\operatorname{Max}-\mathrm{Min})$ \\
\hline District magnitude & $0.35(0.270 .42)$ & $0.74(0.660 .82)$ & 0.39 \\
\hline Party office local & $0.44(0.390 .49)$ & $0.53(0.490 .56)$ & 0.09 \\
\hline Party office national & $0.53(0.490 .56)$ & $0.61(0.570 .66)$ & 0.08 \\
\hline Political office local & $0.47(0.430 .51)$ & $0.53(0.490 .56)$ & 0.06 \\
\hline Political office national & $0.53(0.490 .56)$ & $0.60(0.550 .65)$ & 0.07 \\
\hline
\end{tabular}

Note: $95 \%$ confidence intervals in parentheses. 